Original Research Paper

\title{
The Preference of Trigona sp for pollen various plant species in Kawasan Rumah Pangan Lestari
}

\author{
Wardatul Uyun ${ }^{1 *}, \operatorname{Karnan}^{1}$, M. Yamin ${ }^{1}$ \\ ${ }^{\mathbf{1}}$ Biology Education, Faculty of Teacher Training and Education, University of Mataram, Indonesia.
}

\author{
Article History \\ Received : October $26^{\text {th }}, 2021$ \\ Revised : December 20 $0^{\text {th }}, 2021$ \\ Accepted : December 31 ${ }^{\text {th }}, 2021$ \\ Published : January $05^{\text {th }}, 2022$ \\ *Corresponding Author: \\ Wardatul Uyun, \\ Biology Education, Faculty of \\ Teacher Training and Education, \\ University of Mataram, \\ Indonesia. \\ Email: \\ wardahuyun.yun@gmail.com
}

\begin{abstract}
Kawasan Rumah Pangan Lesatri (KRPL) is one of the efforts that can be done to manage food security in the face of climate change. The management of the potential contained in KRPL is by applying Trigona sp honey bee cultivation which is integrated with agricultural land. The success of honey bee cultivation is highly dependent on the availability of feed in the environment. This study aims to determine the preferences of pollen collected by Trigona sp at KRPL. This type of research is a qualitative research with Chi square analysis. The research sample was bee pollen contained in 14 stup. The research was conducted from July-November. Data collection was carried out in October and November by making observations at KRPL with an area of 784 meters then making plant reference preparations that have the potential to be Trigona sp pollen feed in KRPL and comparing reference preparations with pollen preparations in Trigona sp stup. The results of the research at KRPL showed that there were 20 types of plant pollen in KRPL. The results of the descriptive analysis with chi square showed that there was a preference for the type of pollen that was fed to Trigona sp bees with a value of $\mathrm{x} 2 \mathrm{~h}>\mathrm{x} 2 \mathrm{t}$ so that $\mathrm{H} 0$ was rejected and $\mathrm{Ha}$ was accepted.
\end{abstract}

Keywords: Preference, Pollen, Identification of pollen, Trigona sp.

\section{Pendahuluan}

Parameter iklim secara tidak langsung mempengaruhi semua proses edafik dan biologis. Proses ini akan memiliki dampak terhadap perubahan iklim meskipun besarnya bergantung pada sensitivitas (Shirsath et al., 2017). Perubahan iklim ditandai dengan adanya perubahan cuaca yang tidak menentu contohnya seperti yang dikemukakan oleh Ratnaningayu dalam (Muslim, 2013), yaitu adanya curah hujan yang tidak menentu, sering terjadi badai, suhu udara yang ekstrim, arah angin yang berubah drastis, dan sebagainya. Hal ini akan memperburuk keadaan pada sumber daya darat dan air yaitu menurunnya produktivitas tanaman pangan, ternak dan ikan. Jika tidak segera diambil tindakan atau solusi yang tepat maka efek jangka pendek tidak dapat terhindarkan. Dampak perubahan iklim yang terjadi di dunia memerlukan perhatian serius, khususnya sektor pertanian yang dikemukakan oleh (Santoso,
2016) dampak perubahan iklim ekstrim berupa kekeringan menempati urutan pertama penyebab gagal panen.

Upaya untuk menghadapi perubahan iklim di sektor pertanian dengan menggunakan teknologi unggulan misalnya pemilihan varietas tanaman, pola tanam dan pendekatan pengelolaan ekosistem (Yulianingrum et al., 2019). Salah satu upaya yang dapat dilakukan untuk mengelola ketahanan pangan dalam menghadapi perubahan iklim adalah dengan kawasan rumah pangan lestari. Dalam mengolah potensi yang ada kawasan rumah pangan lestari menggunakan pendekatan melalui pertanian berkelanjutan (sustainable agriculture), yaitu dengan membangun kebun bibit, demplot, kebun sekolah serta mengutamakan sumber daya local disertai dengan pemanfaatan pengetahuan local (Kementrian Pertanian RI, 2018). Salah satu demplot yang dikembangkan di Kawasan Rumah Pangan Lestari Lombok Tengah yaitu budidaya 
lebah madu Trigona sp yang terintegrasi dengan lahan pertanian.

Budidaya lebah Trigona sp telah dikenal dan dilakukan oleh masyarakat di kawasan pedesaan. Usaha budidaya lebah Trigona sp di kawasan pedesaan bisa dilakukan oleh masyarakat sebagai mata pencaharian. Usaha ini memerlukan biaya produksi rendah, namun dapat memberikan kontribusi pendapatan yang cukup tinggi. Pengembangan usaha lebah Trigona sp dapat dijadikan sebagai suatu peluang bisnis yang mempunyai prospek bagus (Kusmanwati, 2018). Hal ini dikarenakan hasil budidaya Trigona sp memiliki kandungan propolis yang jauh lebih banyak (Sabir, 2005). Keberhasilan budidaya lebah madu bergantung pada ketersediaan pakan yang ada dilingkungannya. Menurut Sihombing (2015), pakan lebah madu adalah dalam bentuk nectar, polen, honey dew dan royal jelly. Kondisi ligkungan yang ada di Kawasan Rumah Pangan Lestari di Desa Merta, Kecamatan Praya, Kabupaten Lombok Tengah tergolong dalam rejim suhu panas (Isohyperthermic). Kondisi lingkungan tersebut memungkinkan tumbuhnya beberapa jenis tanaman berbunga yaitu tanaman sayur mayur, tanaman hias dan tanaman herbal yang akan menajdi sumber pakan bagi lebah madu. Potensi tanaman sebagai pakan atau sumber polen yang ada di Kawasan Rumah Pangan Lestari beragam, namun belum ada informasi mengenai jenis tanaman berbunga yang disukai oleh Trigona sp.

Menurut Widowati (2013), polen adalah alat reproduksi jantan pada bunga. Umumnya semua tanaman berbunga merupakan sumber pakan lebah karena bunga adalah penghasil polen. Lebih lanjut DeGrandiHoffman dalam Widowati (2013) ketersediaan dan kualitas polen bunga juga sangat menentukan perkembangan dan kondisi kesehatan koloni terutama bagi jumlah telur, perkembangan larva hingga mencapai dewasa, dan produktivitas koloni. Hasil penelitian oleh Pratama et al., (2018) menyatakan bahwa terdapat perbedaan jenis polen yang dikoleksi oleh Trigona sp pada ketinggian tertentu dan polen yang dikoleksi oleh lebah Trigona sp tergantung dari bunga yang tumbuh disekitar sarangnya. Oleh karena itu, informasi mengenai tanaman-tanaman sumber polen yang cenderung dikunjungi oleh Trigona sp sangat diperlukan untuk menentukan perkembangan koloni dan produktifitas madu. Berdasarkan pemaparan tersebut maka perlu dikaji kecenderungan atau preferensi polen jenis tumbuhan yang disukai oleh lebah Trigona sp di Kawasan Rumah Pangan Lestari Lombok tengah. Penelitian ini dapat memberikan manfaat sebagai sumber informasi untuk budidaya lebah Trigona sp dalam menentukan jenis polen tanaman yang paling bagus untuk perkembangan koloni dan produktifitas madu.

\section{Bahan dan Metode}

\section{Waktu dan tempat}

Penelitian ini dilaksanakan di Kawasan Rumah Pangan Lestari (KRPL) di Desa Mertak, Kecamatan Praya, Kabupaten Lombok Tengah. Luas Kawasan Rumah Pangan Lestari yaitu 784 meter. Waktu penelitian dilaksanakan dalam rentang waktu 6 bulan yang dimulai sejak bulan Juli sampai dengan November.

\section{Alat dan bahan}

Alat yang digunakan dalam penelitian ini adalah aplikasi plan-Net, botol sampel dengan volume $5 \mathrm{ml}$, centrifuge dan tabung centrifuge, gelas objek dan gelas penutup, mikroskop elektrik binokuler, kamera optilab dan imagine raster, pipet tetes dan tisu. Bahan yang digunakan dalam penelitian ini adalah aquades, air hangat, kertas label dan polen lebah Trigona sp.

\section{Pengambilan data}

Pengambilan data dilakukan secara bertahap yaitu bulan Oktober dan November. Adapun langkah-langkah yang dilakukan yaitu, observasi, pembuatan preparate referensi, isolasi polen lebah madu Trigona sp., identifikasi polen jenis tumbuhan di KRPL dan perhitungan jumlah polen.

1. Observasi dilakukan di KRPL dengan luas wilayah 278 meter dari stup untuk mendata jenis tumbuhan menggunakan aplikasi plant-Net.

2. pembuatan preparate referensi dilakukan dengan mengoleksi dan mengamati polen jenis tumbuhan di KRPL dengan menggunakan mikroskop binokuler dan kamera optilab. Bagian polen yang diamati yaitu berupa ukuran polen, apertur dan ornamentasi eksin. 
3. Isolasi polen lebah Trigona sp dilakukan pada bulan November. Berikut tahapan dalam melakukan isolasi polen lebah Trigona sp. yaitu:

a. Mengambil 1 butir polen pada 14 stup lebah Trigona sp di KRPL.

b. Menimbang masings-masing sebanyak 0,1 gr polen lebah Trigona sp menyimpannya dalam botol sampel $5 \mathrm{ml}$.

c. Memberikan label masing-masing pada 14 sampel botol.

d. Mengambil satu botol sampel polen.

e. Memindahkan butir polen ke dalam tabung reaksi.

f. Menambahkan air hangat pada polen Trigona dengan perbandingan 1:2, sambil diaduk.

g. Setelah dingin, sampel polen dimasukkan dalam tabung centrifuge. Bahan disentrifugasi dengan kecepatan $1000 \mathrm{rppm}$. Setelah 15 menit pemusingan, cairan pada tabung dikeluarkan dengan pipet.

h. Mengulangi langkah d, e, dan f pada 13 stup lainnya.

i. Membersihkan alat dan bahan.

4. Identifikasi polen jenis di KRPL dan polen dalam stup

a. Identifikasi polen jenis tumbuhan atau preparate referensi dilakukan dengan mengamati panjang aksis dan ekutorial, bentuk, aperture dan ornamentasi eksin. Menurut Erdtman (1986) dalam Zahrina et al.,(2017) menyatakan bahwa penentuan indeks polar dan ekutorial yaitu dengan membandingkan ukuran panjang aksis polar dan ekutorial untuk menentukan bentuk polen. Pengukuran panjang aksis dan ekutorial dalam penelitian ini menggunakan aplikasi Imagine Raster.

b. Identifikasi polen dalam stup mengacu pada Nugroho \& Soesilohadi (2014) yaitu membandingkan preparat referensi dengan polen jenis tumbuhan dalam stup.

5. Perhitungan jumlah polen lebah madu Trigona sp dilakukan dengan mengamati jumlah polen jenis tumbuhan dalam larutan sentrifugasi menggunakan mikroskop binokuler dengan tambahan kamera optilab.

\section{Analisis data}

Analisis data dilakukan untuk melihat preferensi polen jenis tumbuhan yang disukai oleh lebah Trigona sp yang ada di KRPL Lombok Tengah. Analisis data berupa perhitungan jumlah polen pada 14 stup. Jumlah polen jenis tumbuhan pada 14 stup dihitung secara manual dan dianalisis menggunakan uji Chi-Square. Berikut rumus Chi-Square menurut Wibowo, (2017) untuk mengetahui preferensi polen jenis tumbuhan di KRPL adalah sebagai berikut.

$$
x^{2}=\sum \frac{\left(f_{o}-f_{h}\right)^{2}}{f_{h}}
$$

$$
\begin{aligned}
& \text { Keterangan: } \\
& \chi^{2}=\text { Chi-square } \\
& \text { Fo = Frekuensi yang di observasi } \\
& \text { Fh =Frekuensi yang diharapkan }
\end{aligned}
$$

\section{Hipotesis}

Ha: Terjadi penyimpangan jenis polen tumbuhan tertentu yang dikumpulkan lebah Trigona sp. H0: Tidak terjadi penyimpangan jenis polen tumbuhan tertentu yang dikumpulkan lebah Trigona sp

\section{Hasil dan Pembahasan}

\section{Sumber Pakan Polen di Kawasan Rumah Pangan Lestari}

Kawasan rumah pangan lestari terletak di Desa Merta, Kecamatan Praya Kabupaten Lombok Tengah merupakan salah satu lahan pertanian yang cukup aktif dimana masyarakat umumnya menanam padi, jagung, dan kacangkacangan. Menurut Pratama et al (2018) menyatakan bahwa polen yang dikoleksi oleh lebah Trigona sp bergantung dari bunga yang tumbuh disekitar sarangnya. Berkaitan dengan hal tersebut maka penanaman jenis tanaman harus bervariasi, sehingga persediaan pakan dari tanaman akan tetap tersedia. Jenis tanaman di KRPL cukup beragam yakni terdapat 20 tanaman 
dengan jumlah tanaman dan jarak yang beragam. Umumnya tanaman yang hidup sepanjang musim di KRPL adalah tekokak (Solanum torvum), terong (Solanum melongena), tomat (Solanum lycopersicum), bunga zinnia (Zinnia elegans).

Menurut Pratama et al (2018) menyatakan bahwa jarak jelajah lebah dalam mencari makanan terjauh adalah $488 \mathrm{~m}$ dan jarak terdekat $2 \mathrm{~m}$ dari sarang. Jarak tanaman KRPL terdekat dari stup adalah 1,3meter dan jarak tanaman yang terjauh dari stup lebah adalah 30 meter Berikut tanaman yang terdapat di dalam Kawasan rumah pangan lestari disajikan pada tabel 1.

Tabel 1. Vegetasi tanaman sebagai sumber pakan polen di KRPL

\begin{tabular}{|c|c|c|c|c|c|c|}
\hline No & Family & Nama lokal & Nama latin & Jumlah & $\begin{array}{c}\text { Jarak } \\
\text { stup (m) }\end{array}$ & $\begin{array}{c}\text { Masa } \\
\text { Berbunga }\end{array}$ \\
\hline \multirow[t]{2}{*}{1} & Amaranthaceae & Bayam liar & $\begin{array}{l}\text { (Amaranthus } \\
\text { spinosus) }\end{array}$ & 36 & 15,48 & $\sqrt{ } \sqrt{ }$ \\
\hline & & Bunga Jengger & $\begin{array}{l}\text { (Celosia } \\
\text { plumosa) }\end{array}$ & 8 & 10,12 & $\sqrt{ } \sqrt{ }$ \\
\hline 2 & Apocynaceae & Tapak dara & $\begin{array}{l}\text { (Catharanthus } \\
\text { roseus) }\end{array}$ & 5 & 12,56 & $\sqrt{ } \sqrt{ }$ \\
\hline \multirow[t]{3}{*}{3} & Asteraceae & Bunga kenikir & $\begin{array}{l}\text { (Cosmos } \\
\text { caudatus) }\end{array}$ & 23 & 10,12 & $\sqrt{\sqrt{ }}$ \\
\hline & & Bunga kertas & (Zinnia elegans & 62 & 18,07 & $\sqrt{ } \sqrt{ }$ \\
\hline & & $\begin{array}{l}\text { Bunga } \\
\text { matahari }\end{array}$ & $\begin{array}{l}\text { (Helianthus } \\
\text { annus) }\end{array}$ & 11 & 19,10 & $\sqrt{ }$ \\
\hline 4 & Caricaceae & Pepaya & $\begin{array}{l}\text { (Carica } \\
\text { papaya) }\end{array}$ & 39 & 6,27 & $\sqrt{ } \sqrt{ }$ \\
\hline \multirow[t]{2}{*}{5} & Cucuritaceae & Papasan & $\begin{array}{l}\text { (Cocina } \\
\text { grandis) }\end{array}$ & 4 & 12,56 & $\sqrt{ }$ \\
\hline & & Labu & $\begin{array}{l}\text { (Cucurbita } \\
\text { moschata) }\end{array}$ & 5 & 30 & $\sqrt{ }$ \\
\hline 6 & Leguminoceae & Kacang tanah & $\begin{array}{l}\text { (Arachis } \\
\text { hypogaea) }\end{array}$ & 100 & 30 & $\sqrt{ } \sqrt{ }$ \\
\hline 7 & Oxalidaceae & Belimbing & $\begin{array}{l}\text { (Averrhoa } \\
\text { carambola) }\end{array}$ & 1 & 24,72 & $\sqrt{ }$ \\
\hline 8 & Portulacaceae & Kokot & $\begin{array}{l}\text { (Portulaca } \\
\text { grandiflora) }\end{array}$ & 5 & 11,38 & $\sqrt{ } \sqrt{ }$ \\
\hline 9 & Rutaceae & Limau & $\begin{array}{l}\text { (Citrus } \\
\text { amblycarpa) }\end{array}$ & 1 & 24,56 & $\sqrt{ } \sqrt{ }$ \\
\hline 10 & Sapotaceae & Sawo & $\begin{array}{l}\text { (Maniilkara } \\
\text { zapota) }\end{array}$ & 9 & 1,3 & $\sqrt{ } \sqrt{ }$ \\
\hline \multirow[t]{4}{*}{11} & Solanaceae & Cabai & $\begin{array}{l}\text { (Capsicum } \\
\text { annum) }\end{array}$ & 12 & 18,07 & $\sqrt{ } \sqrt{ }$ \\
\hline & & Terong & $\begin{array}{l}\text { (Solanum } \\
\text { melongena) }\end{array}$ & 139 & 10,12 & $\sqrt{ } \sqrt{ }$ \\
\hline & & $\begin{array}{l}\text { Terong } \\
\text { tekokak }\end{array}$ & $\begin{array}{l}\text { (Solanum } \\
\text { torvum) }\end{array}$ & 4 & 1,5 & $\sqrt{ } \sqrt{ }$ \\
\hline & & Tomat & $\begin{array}{l}\text { (Solanum } \\
\text { lycopersicum). }\end{array}$ & 45 & 9,74 & $\sqrt{ } \sqrt{ }$ \\
\hline 12 & Turneraceae & Bunga pukul 8 & $\begin{array}{l}\text { (Turbunera } \\
\text { subulata) }\end{array}$ & 17 & 1,56 & $\sqrt{ } \sqrt{ }$ \\
\hline 13 & Verbenaceae & $\begin{array}{l}\text { Bunga } \\
\text { tembelek/ } \\
\text { Cente } \\
\end{array}$ & $\begin{array}{l}\text { (Lantana } \\
\text { camara) }\end{array}$ & 4 & 1,10 & $\sqrt{ } \sqrt{ }$ \\
\hline
\end{tabular}

Keterangan: $\sqrt{ }$ : Berbunga pada bulan November $\sqrt{ } \sqrt{ }$ : berbunga pada bulan Oktober dan November 
Berdasarkan hasil penelitian preferensi lebah Trigona sp. terhadap polen dalam berbagai jenis tumbuhan dalam Kawasan rumah pangan lestari yang diperoleh dari Desa Merta, Kecamatan Praya Kabupaten Lombok Tengah, terdapat berbagai macam polen yang memiliki struktur dan morofologi yang berbeda berdasarkan ciri tersebut diketahui takson tumbuhan-tumbuhan yang ada di KRPL. Berdasarkan hasil penelitian dapat diketahui bahwa terdapat 20 jenis tanaman di Kawasan Rumah Pangan Lestari Lombok Tengah yang menjadi sumber polen Trigona sp. Tanaman yang berhasil teridentifikasi tersebut terbagi menjadi 13 famili, yaitu Amaranthaceae, Apocynaceae, Asteraceae, Caricaceae, Cucurbitaceae, Leguminoceae, Oxalidaceae, Portulacaceae, Rutaceae, Sapotaceae, Solanaceae, Turneraceae, dan Verbenaceae. Jumlah tumbuhan yang teridentifikasi sebagai sumber polen di KRPL lebih banyak dibandingkan dengan penelitian Anwar (2002), yang menemukan 5 jenis tanaman di dan termasuk kedalam 4 famili di koloni lebah liar (Apis spp.) Desa Parado, Kabupaten Bima. Hal tersebut dapat disebabkan karena jenis lebah yang digunakan pada penelitian tersebut berbeda dengan penelitian ini, yaitu lebah bergenus Apis.

Tanaman yang memiliki jarak terjauh dari sarang lebah Trigona sp. adalah Kacang Tanah (Arachis Hypogaea) dan Labu (Cucurbita moschata) dengan jarak $30 \mathrm{~m}$. Selanjutnya, tanaman yang memiliki jarak terdekat dengan sarang lebah Trigona sp. adalah Sawo (Manilkara zapota) dan Terong Tekokak (Solanum torvum) dengan jarak kurang dari 1,5 m. Merujuk pada pendapat Warisno (1996), bahwa dekatnya jarak antara sarang lebah dengan bunga (sumber pakan) akan memungkinkan jumlah polen yang terambil oleh lebah lebih banyak dikarenakan energi yang digunakan lebah lebih sedikit. Hal tersebut juga dibuktikan oleh Anwar (2002), bahwa tingginya jumlah polen dari Cocos nucifera dan tumbuhan famili Asteraceae dikarenakan jaraknya yang lebih dekat dengan sarang lebah Apis spp.

Merujuk pada Priambudi et al (2021), yang menyatakan bahwa ketersediaan pakan lebah secara berkesinambungan menjadi salah satu faktor pendukung perkembangan koloni lebah dan produksi madu. Berdasarkan masa berbunga tanaman yang terdapat di Kawasan rumah pangan lestari menunjukkan adanya perbedaan waktu tanaman dalam menyediakan pakan bagi lebah Trigona sp. tanaman yang berbunga hanya pada bulan november adalah bunga matahari (Helianthus annus). Sedangkan tanaman lainnya memilki masa berbunga yang sama yaitu berbunga pada bulan Oktober dan November. Hal ini sejalan dengan hasil penelitian oleh Setiawan et al., (2021) yakni produk lebah yang dihasilkan berupa madu, propolis dan telur menggunakan tekhnik kandang lebih berat dibandingkan menggunakan tekhnik patok dan gantung. Hal ini dikarenakan adanya perbedaan predator dan sumber pakan. Pada teknik kandang, sumber pakan melimpah di sekitar sarang lebah karena banyak tumbuhan bunga dan buah, serta jaraknya relatif dekat sekitar $500 \mathrm{~m}$ dari stup. Sedangkan untuk teknik patok, lingkungan di sekitarnya berupa hutan bambu dan pepohonan sehingga madu yang dihasilkan tidak sebanyak teknik kandang.

\section{Identifikasi Polen Jenis Tanaman di Kawasan Rumah Pangan Lestari}

Identifikasi polen jenis tumbuhan di KRPL dilakukan dengan mengamati bentuk polen, apertur dan ornamentasi eksin. Pengamatan aperture dan ornamentasi polen jenis tumbuhan di KRPL merujuk pada Nugroho, (2014). Sedangkan untuk menentukan bentuk polen dilakukan dengan mengukur panjang aksis polar dan ekutorial polen yang merujuk pada Erdmant (1972) dalam Fauzia et al (2019) yaitu: Peroblate : P/E x $100=<50 \mu \mathrm{m}$, Oblate : P/E x $100=50-<75 \mu \mathrm{m}$, Subspheroidal $: \mathrm{P} / \mathrm{E} \times 100=$ $75-<133 \mu \mathrm{m}$, Suboblate : P/E x $100=75-<88$ $\mu \mathrm{m}$, Oblate spheroidal : P/E x $100=88-<100 \mu \mathrm{m}$, Prolate spheroidal : $\mathrm{P} / \mathrm{E} \times 100=100-<114 \mu \mathrm{m}$, Subprolate : P/E x $100=115-<133 \mu \mathrm{m}$, Prolate : $\mathrm{P} / \mathrm{E}$ x $100=133-200 \mu \mathrm{m}$ dan Perprolate $: \mathrm{P} / \mathrm{E}$ x $100=>200 \mu \mathrm{m}$. Selanjutnya Erdmant (1972) Fauzia et al (2019) mengelompokan bentuk polen berdasarkan ukuran aksis terpanjang yang terdiri atas Very small $(<10 \mu \mathrm{m})$, Kecil $(10-$ $25 \mu \mathrm{m})$, Medium $(25-50 \mu \mathrm{m})$, Large $(50-100 \mu \mathrm{m})$, Very large $(100-200 \mu \mathrm{m})$ dan Gigantic

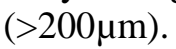

Morfologi polen pada setiap tanaman juga memiliki karakteristiknya masing-masing. 
Morfologi polen yang teramati adalah 6 macam bentuk polen, 7 macam aperture, dan 5 macam ornamentasi eksin. Bentuk polen jenis tumbuhan di KRPL beragam dan termasuk dalam bentuk polen ukuran large $(50-100 \mu \mathrm{m})$. begitu juga dengan apertur dan ornamentasi eksin pada polen jenis tumbuhan di KRPL. Meskipun termasuk kedalam famili Amaranthaceae, Bayam (Amaranthus spinosus) dan Bunga Jengger (Celosia plumosa) memiliki morfologi yang berbeda, baik dari segi bentuk, tipe aperture, dan ornamentasi eksinnya. Berbeda halnya dengan jenis tumbuhan dari famili Asteraceae yang hanya memiliki perbedaan pada bentuk polennya sedangkan tipe aperture dan ornamentasi eksinnya memiliki kesamaan. Bunga Kenikir (Cosmos caudatus) dan Bunga Kertas (Zinnia elegans) memiliki bentuk polen Prolate spheroidal sedangkan Bunga matahari (Helianthus annus) memiliki bentuk polen Oblate spheroidal. Begitu juga pada beberapa jenis tanaman lainnya. Menurut Pertiwi et al., (2015) menyatakan bahwa adanya persamaan pada ciri morfologi tersebut dikarenakan jenisjenis tumbuhan ini tergolong dalam satu famili yang merupakan ciri khas dari famili Asteraceae. Selain itu terdapat beberapa jenis polen yang tidak sama dengan karakter morfologi yang dimaksud, hal ini dikarenakan memungkinkan jenis tersebut merupakan golongan taksonomi yang berbeda dengan famili yang dimaksud atau jenis tersebut digolongankan termasuk ke dalam takson di bawah spesies. Oleh karena adanya perbedaan ciri morfologi tersebut maka polen dapat digunakan untuk mengidentifikasi mengidentifikasi takson di tingkat famili, genus, spesies dan di bawah spesies, penempatan taksa yang diragukan, penyusunan kembali, penggabungan dan pemisahan serta sebagai sumber bukti taksonomi yang penting. Berikut disajikan hasil identifikasi polen jenis tanaman di KRPL pada tabel 2.

Tabel 2. Identifikasi polen jenis tanaman di KRPL

\begin{tabular}{|c|c|c|c|c|c|c|c|}
\hline \multirow[t]{2}{*}{ No } & \multirow[t]{2}{*}{ Objek } & \multicolumn{2}{|c|}{$\begin{array}{c}\text { Panjang aksis } \\
\text { polar }(\mathbf{P}) \text { dan } \\
\text { diameter ekutorial } \\
\end{array}$} & \multirow{2}{*}{$\begin{array}{c}\text { Indeks } \\
\text { P/E } \\
\text { x100 }\end{array}$} & \multirow{2}{*}{ Bentuk } & \multirow{2}{*}{ Aperture } & \multirow{2}{*}{$\begin{array}{c}\text { Ornamentasi } \\
\text { Eksin }\end{array}$} \\
\hline & & $\mathbf{P}$ & $\mathbf{E}$ & & & & \\
\hline 1 & $\begin{array}{l}\text { Bayam liar } \\
\text { (Amaranthus } \\
\text { spinosus). } \\
\end{array}$ & 4,16 & 4,04 & 102,97 & $\begin{array}{l}\text { Prolate } \\
\text { spheroidal }\end{array}$ & Polyporate & Verukat \\
\hline 2 & $\begin{array}{l}\text { Belimbing } \\
\text { (Averrhoa } \\
\text { carambola) }\end{array}$ & 4,32 & 2,81 & 153,74 & Prolate & Tricopate & Psilate \\
\hline 3 & $\begin{array}{l}\text { Bunga Jengger } \\
(\text { Celosia plumosa })\end{array}$ & 1,42 & 1,21 & 117,36 & Subprolate & Colpate & Psilate \\
\hline 4 & $\begin{array}{c}\text { Bunga kenikir } \\
\text { (Cosmos caudatus } \\
\text { Kunth) }\end{array}$ & 4,04 & 3,69 & 109,49 & $\begin{array}{c}\text { Prolate } \\
\text { spheroidal }\end{array}$ & Pantoporate & Echinate \\
\hline 5 & $\begin{array}{l}\text { Bunga kertas (Zinnia } \\
\text { elegans jaqc). }\end{array}$ & 4,14 & 4,14 & 100,00 & $\begin{array}{c}\text { Prolate } \\
\text { spheroidal }\end{array}$ & Pantoporate & Echinate \\
\hline 6 & $\begin{array}{c}\text { Bunga matahari } \\
\text { (Helianthus annus) }\end{array}$ & 4,45 & 4,98 & 89,36 & $\begin{array}{l}\text { Oblate } \\
\text { spheroidal }\end{array}$ & Pantoporate & Echinate \\
\hline 7 & $\begin{array}{l}\text { Bunga pukul } 8 \\
\text { (Turbunera } \\
\text { subulata) }\end{array}$ & 4,43 & 4,51 & 98,23 & Spheroidal & Tricolporate & Reticulate \\
\hline
\end{tabular}




\begin{tabular}{|c|c|c|c|c|c|c|c|}
\hline \multirow[t]{2}{*}{ No } & \multirow[t]{2}{*}{ Objek } & \multicolumn{2}{|c|}{$\begin{array}{c}\text { Panjang aksis } \\
\text { polar (P) dan } \\
\text { diameter ekutorial }\end{array}$} & \multirow{2}{*}{$\begin{array}{c}\text { Indeks } \\
\text { P/E } \\
\text { x100 }\end{array}$} & \multirow[t]{2}{*}{ Bentuk } & \multirow[t]{2}{*}{ Aperture } & \multirow{2}{*}{$\begin{array}{c}\text { Ornamentasi } \\
\text { Eksin }\end{array}$} \\
\hline & & $\mathbf{P}$ & $\mathbf{E}$ & & & & \\
\hline 8 & $\begin{array}{l}\text { Bunga tembelek/ } \\
\text { Cente (Lantana } \\
\text { camara) }\end{array}$ & 6,83 & 6,64 & 102,86 & $\begin{array}{c}\text { Prolate } \\
\text { spheroidal }\end{array}$ & Tricolporate & Rugulate \\
\hline 9 & $\begin{array}{c}\text { Cabai (Capsicum } \\
\text { annum) }\end{array}$ & 4,51 & 4,43 & 101,81 & $\begin{array}{c}\text { Prolate } \\
\text { spheroidal }\end{array}$ & Tricolpate & Psilate \\
\hline 10 & $\begin{array}{c}\text { Kacang tanah } \\
\text { (Arachis hypogaea) }\end{array}$ & 5,86 & 4,58 & 127,95 & Subprolate & Monocolpate & Psilate \\
\hline 11 & $\begin{array}{l}\text { Kokot (Portulaca } \\
\text { grandiflora) }\end{array}$ & 5,74 & 6,15 & 93,33 & $\begin{array}{c}\text { Oblate } \\
\text { spheroidal }\end{array}$ & Pantoporate & Scabrate \\
\hline 12 & $\begin{array}{c}\text { Limau (Citrus } \\
\text { amblycarpa) }\end{array}$ & 3,15 & 2,02 & 155,94 & Prolate & Dicolpet & Psilate \\
\hline 13 & $\begin{array}{c}\text { Papasan (Cocina } \\
\text { grandis) }\end{array}$ & 6,47 & 5,81 & 111,36 & Subprolate & Dicolpet & Reticulate \\
\hline 14 & $\begin{array}{c}\text { Labu (Cucurbita } \\
\text { moschata) }\end{array}$ & 8,33 & 9,99 & 83,38 & $\begin{array}{c}\text { Oblate } \\
\text { spheroidal }\end{array}$ & Dicolpet & Echinate \\
\hline 15 & $\begin{array}{c}\text { Pepaya (Carica } \\
\text { papaya) }\end{array}$ & 5,06 & 5,09 & 99,41 & $\begin{array}{c}\text { Oblate } \\
\text { spheroidal }\end{array}$ & Triporate & Psilate \\
\hline 16 & $\begin{array}{c}\text { Sawo (Maniilkara } \\
\text { zapota) }\end{array}$ & 6,93 & 6,27 & 110,53 & Subprolate & Tricolpate & Scabrate \\
\hline 17 & $\begin{array}{c}\text { Tapak dara } \\
\text { (Catharanthus } \\
\text { roseus) }\end{array}$ & 4,68 & 4,7 & 99,57 & $\begin{array}{c}\text { Oblate } \\
\text { spheroidal }\end{array}$ & Triporate & Scabrate \\
\hline 18 & $\begin{array}{l}\text { Terong (Solanum } \\
\text { melongena) }\end{array}$ & 4,17 & 2,83 & 147,35 & Prolate & Monoporate & Psilate \\
\hline 19 & $\begin{array}{l}\text { Terong tekokak } \\
\text { (Solanum torvum) }\end{array}$ & 4,07 & 4,31 & 94,43 & $\begin{array}{c}\text { Oblate } \\
\text { spheroidal }\end{array}$ & Monoporate & Psilate \\
\hline 20 & $\begin{array}{l}\text { Tomat (Solanum } \\
\text { lycopersicum). }\end{array}$ & 3,93 & 3,86 & 101,81 & $\begin{array}{c}\text { Prolate } \\
\text { spheroidal }\end{array}$ & Monoporate & Psilate \\
\hline
\end{tabular}

Preferensi polen lebah Trigona sp di Kawasan Rumah Pangan Lestari

Preferensi polen jenis tumbuhan ditentukan berdasarkan hasil perhitungan Chi square. Nilai preferensi didapatkan dengan membandingkan nilai chi tabel dengan chi hitung yang menunjukkan bahwa terdapat preferensi jenis pakan polen di KRPL. Chi hitung didapatkan dengan membandingkan jumlah tanaman di KRPL dengan jumlah polen yang ditemukan dalam stup lebah Trigona sp. Berikut disajikan hasil analisis Chi square pada tabel 3. 
Tabel 3. Analisis Chi Square polen jenis tumbuhan di KRPL.

\begin{tabular}{|c|c|c|c|c|c|c|}
\hline \multirow{2}{*}{ No } & \multicolumn{2}{|c|}{ Nama Spesies } & \multicolumn{4}{|c|}{ Jumlah } \\
\hline & Indonesia & Ilmiah & fh & Fo & deviasi & Chi Square Hitung \\
\hline 1 & Bayam liar & Amaranthus spinosus & 36 & 29 & -7 & 1.4 \\
\hline 2 & Belimbing & Averrhoa carambola & 1 & 125 & 124 & 15376,0 \\
\hline 3 & Bunga Jengger & Celosia plumosa & 8 & 46 & 38 & 180,5 \\
\hline 4 & Bunga kenikir & Cosmos caudatus & 23 & 172 & 149 & 965,3 \\
\hline 5 & Bunga kertas & Zinnia elegans & 62 & 260 & 198 & 632,3 \\
\hline 6 & Bunga matahari & Helianthus annus & 11 & 399 & 388 & 13685,8 \\
\hline 7 & Bunga pukul 8 & Turbunera subulata & 17 & 99 & 82 & 395,5 \\
\hline 8 & Bunga tembelek/ Cente & Lantana camara & 4 & 13 & 9 & 20,3 \\
\hline 9 & Cabai & Capsicum annum & 12 & 268 & 256 & 5461,3 \\
\hline 10 & Kacang tanah & Arachis hypogaea & 100 & 235 & 135 & 182,3 \\
\hline 11 & Kokot & Portulaca grandiflora & 5 & 20 & 15 & 45,0 \\
\hline 12 & Limau & Citrus amblycarpa & 1 & 43 & 42 & 1764,0 \\
\hline 13 & Papasan & Cocina grandis & 4 & 80 & 76 & 1444,0 \\
\hline 14 & Labu & Cucurbita moschata & 5 & 1 & -4 & 3,2 \\
\hline 15 & Pepaya & Carica papaya & 39 & 245 & 206 & 1088,1 \\
\hline 16 & Sawo & Maniilkara zapota & 9 & 68 & 59 & 386,8 \\
\hline 17 & Tapak dara & Catharanthus roseus & 5 & 181 & 176 & 6195,2 \\
\hline 18 & Terong & Solanum melongena & 139 & 408 & 269 & 520,6 \\
\hline 19 & Terong tekokak & Solanum torvum & 4 & 580 & 576 & 82944,0 \\
\hline 20 & Tomat & Solanum lycopersicum & 45 & 165 & 120 & 320,0 \\
\hline \multicolumn{3}{|c|}{ Total } & 530 & 3437 & 2907 & 131611,49 \\
\hline & & Chi Hitung & & & & 131611,49 \\
\hline & & Chi Tabel & & & & 31,41 \\
\hline
\end{tabular}

Langkah selanjutnya yaitu menggunakan tabel $X^{2}$. Adapun untuk menggunakan tabel $X^{2}$ diperlukan derajat kebebasan atau dk (degree of freedom" atau df). Derajat kebebasan atau dk adalah jumlah kelas dikurangi satu. Diketahui jumlah kelas pada hasil penelitian adalah 20 sehingga derajat kebebasan pada hasil penelitian adalah 19 dan nilai chi hitung adalah 17836.32 Berdasarkan nilai chi hitung dapat diketahui bahwa $\mathrm{P}$ Value < 0.01 ataupun $<0.05$ yang membuktikan bahwa ada penyimpangan, yaitu jumlah pohon di KRPL beragam namun hanya polen jenis tertentu yang dikumpulkan oleh Trigona $s p$. Oleh karena itu dapat disimpulkan bahwa Ha diterima dan $\mathrm{H} 0$ ditolak sehingga terdapat perbedaan preferensi polen jenis yang dikumpulkan oleh lebah Trigona sp. di Kawasan Rumah Pangan Lestari. Berikut disajikan tabel $\mathrm{X}^{2}$ menurut Sugiyono (2014) pada tabel 4.

Tabel 4. Tabel X ${ }^{2}$

\begin{tabular}{ccccccc}
\hline Derajat kebebasan & \multicolumn{7}{c}{ Taraf Signifikansi } \\
\cline { 2 - 7 } & $50 \%$ & $30 \%$ & $20 \%$ & $10.0 \%$ & $5 \%$ & $1 \%$ \\
\hline 1 & 0,455 & 1,074 & 1,642 & 2,706 & 3,841 & 6,635 \\
2 & 1,368 & 2,408 & 3,219 & 4,605 & 5,991 & 9,21
\end{tabular}




\begin{tabular}{|c|c|c|c|c|c|c|}
\hline \multirow[t]{2}{*}{ Derajat kebebasan } & \multicolumn{6}{|c|}{ Taraf Signifikansi } \\
\hline & $50 \%$ & $30 \%$ & $20 \%$ & $10.0 \%$ & $5 \%$ & $1 \%$ \\
\hline 3 & 2,366 & 3,665 & 4,642 & 6,251 & 7,815 & 11,341 \\
\hline 4 & 3,357 & 4,878 & 5,989 & 7,779 & 9,488 & 13,277 \\
\hline 5 & 4,351 & 6,064 & 7,289 & 9,236 & 11,07 & 15,086 \\
\hline 6 & 5,348 & 7,231 & 8,558 & 10,645 & 12,592 & 16,812 \\
\hline 7 & 6,346 & 8,383 & 9,803 & 12,017 & 14,067 & 18,475 \\
\hline 8 & 7,344 & 9,524 & 11,030 & 13,362 & 15,507 & 20,09 \\
\hline 9 & 8,343 & 10,658 & 12,242 & 14,684 & 16,919 & 21,666 \\
\hline 10 & 9,342 & 11,781 & 13,442 & 15,987 & 18,307 & 23,209 \\
\hline 11 & 10,341 & 12,899 & 14,631 & 17,275 & 19,675 & 24,725 \\
\hline 12 & 11,340 & 14,011 & 15,812 & 18,812 & 21,026 & 26,217 \\
\hline 13 & 12,340 & 15,119 & 16,985 & 19,812 & 22,362 & 27,688 \\
\hline 14 & 13,339 & 16,151 & 18,151 & 21,064 & 23,685 & 29,141 \\
\hline 15 & 14,339 & 17,322 & 19,311 & 22,307 & 24,996 & 30,578 \\
\hline 16 & 15,338 & 18,418 & 20,465 & 23,542 & 26,269 & 32,000 \\
\hline 17 & 16,338 & 19,511 & 21,615 & 24,769 & 27,587 & 33,409 \\
\hline 18 & 17,338 & 20,601 & 22,760 & 25,989 & 28,869 & 34,805 \\
\hline 19 & 18,338 & 21,689 & 23,900 & 27,204 & 30,41 & 36,191 \\
\hline 20 & 19,337 & 22,775 & 25,038 & 28,412 & 31,41 & 37,566 \\
\hline 21 & 20,337 & 23,858 & 26,171 & 29,615 & 32,671 & 38,932 \\
\hline 22 & 21,337 & 24,939 & 27,301 & 30,813 & 33,924 & 40,289 \\
\hline 23 & 22,337 & 26,018 & 28,429 & 32,007 & 35,172 & 41,638 \\
\hline 24 & 23,337 & 27,096 & 29,553 & 33,196 & 35,415 & 42,980 \\
\hline 25 & 24,337 & 28,172 & 30,675 & 34,382 & 37,652 & 44,314 \\
\hline 26 & 25,336 & 29,264 & 31,795 & 35,563 & 38,885 & 45,642 \\
\hline 27 & 26,336 & 30,319 & 32,912 & 36,741 & 40,113 & 46,963 \\
\hline 28 & 27,336 & 31,391 & 34,027 & 37,916 & 41,337 & 48,278 \\
\hline 29 & 28,336 & 32,461 & 35,139 & 39,087 & 42,557 & 49,588 \\
\hline 30 & 29,336 & 33,530 & 36,250 & 40,256 & 43,773 & 50,892 \\
\hline
\end{tabular}

Preferensi dalam Kamus Besar Bahasa Indonesia (KBBI) adalah pilihan, kecenderungan, minat atau kesukaan. Penentuan perbedaan preferensi polen pada lebah Trigona sp. menggunakan analisis statistik deskriptif Chi Square $\left(x^{2}\right)$. Penggunan analisis tersebut dikarenakan pada penelitian ini hanya menggunakan satu variabel mandiri, yaitu jumlah polen (Sugiyono, 2014). Hasil analisis data menunjukan bahwa terdapat perbedaan preferensi polen jenis yang dikumpulkan oleh lebah Trigona sp. yang dibuktikan dengan nilai $\mathrm{x}^{2} \mathrm{~h}>\mathrm{x}^{2} \mathrm{t}$ sehingga $\mathrm{H}_{\mathrm{a}}$ diterima dan $\mathrm{H} 0$ ditolak (Tabel 7) dan $P$ Value $<0.01$ ataupun $<0.05$ yang membuktikan bahwa ada penyimpangan yang berarti terdapat preferensi polen jenis tanaman tertentu yang dikumpulkan oleh lebah Trigona $s p$. Perbedaan preferensi polen tersebut ditunjukan dengan banyaknya pohon yang berada di KRPL namun hanya polen jenis tumbuhan tertentu yang dikumpulkan oleh lebah Trigona $s p$. Tanaman yang polennya ditemukan melimpah adalah Terong Tekokak (Solanum torvum), Terong (Solanum melongena), dan Bunga Matahari (Helianthus annus) yang secara berturut berjumlah 580, 408 dan 399 butir polen.

Berdasarkan jumlah tanaman di KRPL ditemukan bahwa tanaman yang memiliki jumlah polen yang tinggi yaitu Terong Tekokak (Solanum torvum), Terong (Solanum melongena) 
dan Bunga Matahari (Helianthus annus) memiliki jarak tanaman yang dekat dengan stup lebah Trigona sp. Hal ini menunjukkan bahwa semakin dekat jarak tanaman dari stup maka semakin banyak polen yang dikumpulkan oleh lebah Trigona sp. Hal ini berkaitan dengn energi yang digunakan lebah lebih sedikit. Tingginya jumlah polen yang dikumpulkan oleh lebah juga berkaitan dengan ketersediaan pakan yang ada dilingkungannya. Menurut Priambudi et al (2021), yang menyatakan bahwa ketersediaan pakan lebah secara berkesinambungan menjadi salah satu faktor pendukung perkembangan koloni lebah dan produksi madu. Ketersediaan pakan bergantung pada masa berbunga tanaman, jika pakan yang tersedia melimpah maka produksi atau polen yang dikumpulkan oleh lebah akan meningkat. Hal ini sejalan dengan hasil penelitian oleh Saepudin et al (2011) Produksi madu dari lebah yang dipelihara lebih tinggi dari produksi madu dari lebah yang dipelihara di luar kawasan integrasi.hal ini dikarenakan ketersediaan pakan berupa jumlah tanaman cukup tinggi dan memiliki masa berbunga yang sama dikarenakan hanya terdiri dari satu jenis tanaman saja.

\section{Kesimpulan}

Berdasarkan tujuan, hasil dan pembahasan mengenai preferensi Trigona sp. terhadap polen berbagai jenis tumbuhan di Kawasan Rumah Pangan Lestari diperoleh kesimpulan yaitu terdapat preferensi polen jenis tumbuhan di Kawasan Rumah Pangan Lestari yakni terdapat 20 polen jenis tumbuhan namun hanya polen jenis tertentu yang dikumpulkan oleh lebah Trigona sp.

\section{Ucapan terima kasih}

Tim penelitian menyampaikan ucapan terima kasih kepada Dekan FKIP Universitas Mataram yang telah memberikan fasilitas laboratorium untuk pelaksaan penelitian.

\section{Referensi}

Anwar, K. (2002). Serbuk Sari Terbawa Pada Jenis Madu Merah Yang Diperoleh Dari Desa Parado Kecamatan Monta Kabupaten Bima. Universitas Mataram.
Eti Kusmanwati (2018). Analisis Rentabilitas Usaha Budidaya Lebah Madu Trigona Sp Di Kabupaten Lombok Barat. -.

Fauzia, Salma \& Sukarsa, H. W. (2019). Karakteristik Morfologi Polen Sebagai Sumber Pakan Lebah Trigona sp.di Desa Serang, Purbalingga. 1. http://webcache.googleusercontent.com/s earch?q=cache:_umurRuuEDcJ:jos.unsoe d.ac.id/index.php/bioe/article/download/1 $809 / 1248 /+\& c d=14 \&$ hl=id\&ct=clnk\&gl= id

Kementrian Pertanian RI (2018). Petunjuk Teknis Optimalisasi Pemanfaatan Lahan Pekarangan Melalui Kawasan Rumah Pangan Lestari (KRPL).

Muslim, C. (2013). Mitigasi Perubahan Iklim dalam Mempertahankan Produktivitas Tanah Padi Sawah ( Studi kasus di Kabupaten Indramayu ) Climate Change Mitigation In Maintaining Land Productivity Rice Rice Fields ( Cases; Regency of Indramayu ) Chairul Muslim Indonesian Cent. Jurnal Penelitian Pertanian Terapan, 13(3), 211-222.

Nugroho, R. B., \& Soesilohadi, R. H. (2014). Identifikasi macam sumber pakan lebah Trigona sp (Hymenoptera: Apidae) di Kabupaten Gunungkidul. Biomedika, 7(2), $42-45$.

Nugroho, S. H. (2014). Karakteristik Umum Polen Dan Spora Sertaaplikasinya. Xxxix, 7-19.

Pertiwi, R. H., Hendra, M., Jurusan, M., Fmipa, B., \& Mulawarman, U. (2015). Studi Palinologi Famili Asteraceae di Kebun Raya Universitas Mulawarman Samarinda (Krus). Prosiding Seminar Tugas Akhir FMIPA UNMUL, 1(1), 1-7.

Pratama, I. P. N. E., Watiniasih, N. L., \& Ginantra, I. K. (2018). Perbedaan Ketinggian Tempat Terhadap Jenis Polen Yang Dikoleksi Oleh Lebah Trigona. Jurnal Biologi Udayana, 22(1), 42-48. https://doi.org/10.24843/JBIOUNUD.201 


$$
\text { 8.v22.i01.p06 }
$$

Priambudi, A. S., Rika, Raffiudin. \& Djuita, N. R. . (2021). Identifikasi Tumbuhan Sumber Polen pada Madu Lebah Heterotrigona itama dan Tetragonula laeviceps di Belitung Identification of Plants as Pollen Source in Honey of Stingless Bee Heterotrigona itama and Tetragonula laeviceps from Belitung. Jurnal Sumberdaya Hayati 7(1), 25-35.

Sabir, A. (2005). Aktivitas antibakteri flavonoid propolis Trigona $\mathrm{sp}$ terhadap bakteri Streptococcus mutans (in vitro) (In vitro antibacterial activity of flavonoids Trigona sp propolis against Streptococcus mutans). Dental Journal (Majalah Kedokteran Gigi), 38(3), 135. https://doi.org/10.20473/j.djmkg.v38.i3.p 135-141

Saepudin, R., Fuah, A. M. \& Abdullah, L. (2011). Peningkatan Produktivitas Lebah Madu Melalui Penerapan Sistem Integrasi dengan Kebun Kopi. Jurnal Sain Peternakan Indonesia, 6(2), 115-124. https://doi.org/10.31186/jspi.id.6.2.115124

Santoso, A. B. (2016). Pengaruh Perubahan Iklim terhadap Produksi Tanaman Pangan di Provinsi Maluku. Jurnal Penelitian Pertanian Tanaman Pangan, 35(1), 29. https://doi.org/10.21082/jpptp.v35n1.201 6.p29-38

Setiawan, A., Susdiyanti, T., Bintani Meiganati, K., Sultan Iskandar Muda, J., Lama, K., Selatan, J., Sholeh Iskandar KM, J. K., Cibadak, K., Tanah Sereal, K., \& Bogor, K. (2021). Produktifitas Lebah Trigona Sp. Pada Berbagai Teknik Budidaya di Desa Nayagati Kecamatan Leuwidamar Kabupaten Lebak (Productivity Of The Trigona Sp. Bee On Various Cultivation Technique In Nayagati Village,
Leuwidamar District, Lebak Regency). Jurnal Nusa Sylva, 21(1), 26-31.

Shirsath, P. B., Aggarwal, P. K., Thornton, P. K., \& Dunnett, A. (2017). Prioritizing climate-smart agricultural land use options at a regional scale. Agricultural Systems, 151 , 174-183. https://doi.org/10.1016/j.agsy.2016.09.01 8

Sihombing, D. T. (2015). Ilmu Ternak Lebah Madu. Gajah Mada University.Yogyakarta

Sugiyono (2014). Statistika untuk Penelitian. Alfabeta. Bandung

Warisno (1996). Budidaya Lebah Madu. Kansius. Yogyakarta

Wibowo, A. (2017). Uji Chi-Square pada Statistika dan SPSS. Jurnal Ilmiah SINUS, 4(2), 38 .

Widowati, R. (2013). Pollen Substitute Pengganti Serbuk Sari Alami bagi Lebah Madu. Journal WIDYA Kesehatan Dan Lingkungan, 1(1), 31-36.

Yulianingrum, H., Susilawati, H. L. \& Pramono, A. (2019). Penerapan Paket Teknologi Ramah Lingkungan Untuk Mengurangi Emisi Metana (CH4) Di Lahan Sawah. Jurnal Ilmu Lingkungan, 17(1), 149. https://doi.org/10.14710/jil.17.1.149-157

Zahrina, Hasanuddin, \& Wardiah. (2017). Studi Morfologi Serbuk Sari Enam Anggota Familia Rubiaceae Zahrina $1 *$, Hasanuddin 2, Wardiah 2 1. Jurnal Ilmiah Mahasiswa Fakultas Keguruan Dan Ilmu Pendidikan Unsyiah, 2(1), 114-123. http://www.jim.unsyiah.ac.id/pendidikanbiologi/article/view/2127 